\title{
Recently surveyed lakes in northern Manitoba and Saskatchewan, Canada: characteristics and critical loads of acidity
}

\author{
Dean S. JEFFRIES*, Raymond G. SEMKIN, John J. GIBSON ${ }^{1)}$ and Isaac WONG \\ Environment Canada, National Water Research Institute, Burlington, ON L7R 4A6, Canada \\ ${ }^{1)}$ Alberta Research Council, Victoria, BC V8Z 7X8, Canada \\ *e-mail corresponding author: dean.jeffries@ec.gc.ca
}

\section{ABSTRACT}

Based on minimal information, lakes in the western Canadian provinces of Manitoba (MB) and Saskatchewan (SK) have long been considered unaffected by acid rain. However, emissions of acidifying pollutants from MB smelters and oil sand processing in Alberta (AB) may pose a developing threat. Surveys of 347 lakes located on geologically sensitive terrain in northern MB and SK were conducted to assess their acidification sensitivity and status. The survey domain $\left(\sim 193,000 \mathrm{~km}^{2}\right)$ contained 81,494 lakes $\geq 1$ ha in area. Small lakes dominated the inventory in terms of numbers, and large lakes dominated in terms of area. Survey lakes were selected using a stratified-random sampling design in 10 sampling blocks within the overall survey domain. Few lakes had pH $<6$, and only three (all in SK) were acidic, i.e., Gran Alkalinity (Alk) $<0 \mu \mathrm{eq} L^{-1}$. A broad range in lake sensitivity was apparent, and very sensitive lakes (low specific conductance, base cations and Alk) were present in all sampling blocks. Dissolved organic carbon (DOC) was an important constituent of many lakes. Critical loads (CL) of acidity calculated using the Steady-State Water Chemistry model (SSWC) revealed extremely low 5th percentile values for every block (range 1.9 to 52.7 eq ha $\mathrm{y}^{-1}$ ). Block CL exceedances calculated using estimated $S$ and $N$ deposition for 2002 ranged from 54.5 to 909 eq ha $a^{-1} y^{-1}$. The largest exceedances were for sampling blocks located near smelter sources or downwind of the oil sands. Lake chemistry revealed by our surveys was compared to others conducted both nearby and outside Canada.

Key words: regional lake survey, lake chemistry, acid sensitivity, acidification status, critical loads and exceedances

\section{INTRODUCTION}

Chemical and biological aquatic effects of acid rain occur where geologically sensitive terrain coincides with elevated levels of sulphur (S) and nitrogen $(\mathrm{N})$ deposition. In Canada, enormous regions of sensitive terrain are associated with an east-west arc of Precambrian geological formations collectively known as the Canadian Shield (Environment Canada 1988). Igneous and metamorphic silicate bedrock overlain by glaciallyderived deposits of variable thickness typifies Shield geology.

Until recently, the region of concern for acid rain effects in Canada was restricted to the central and southern parts of the provinces of Ontario and Quebec, plus New Brunswick, Nova Scotia and Newfoundland (Jeffries et al. 2003). This was because anthropogenic sources of acidifying emissions $\left(\mathrm{SO}_{2}\right.$ and $\left.\mathrm{NO}_{\mathrm{x}}\right)$ in western Canada were either too small or too distant from sensitive terrain to be considered a problem. However, ongoing $\mathrm{SO}_{2}$ emissions from base metal smelters at Thompson and Flin Flon in $\mathrm{MB}$ and increasing $\mathrm{SO}_{2}$ and $\mathrm{NO}_{\mathrm{x}}$ emissions from oil sand operations near Fort McMurray, AB (Fig. 1) suggest that sensitive terrain located on the Shield in the northern parts of MB and Saskatchewan (SK) may now be at risk.

In the most recent national assessment of acid rain science in Canada, Jeffries et al. (2005) concluded that the information available for evaluating the regional acidification status of lakes in many parts of western Canada was too old, too sparse or too unrepresentative to permit a meaningful analysis. Conducting new and representative lake surveys was recommended. Our purpose here is to present results from lake surveys conducted on the Canadian Shield in MB and SK in 2006 and 2007 that enable evaluation of regional acid sensitivity and acidification status in potentially acid sensitive regions through calculation of critical loads (CL) and exceedances (Henriksen et al. 2002; Jeffries \& Ouimet 2005). In addition, the results will be compared to those from other nearby or overlapping surveys conducted by Hudson Bay Mining and Smelting Ltd. and Vale Inco Ltd. in 2005 and 2006 (UMA 2007a, b) and the Saskatchewan Ministry of Environment in 2007 and 2008 (Scott et al. 2010, this issue).

\section{METHODS}

\subsection{Study location}

We used the national acid sensitivity map based on bedrock and soil characteristics (Environment Canada 1988 ) to guide selection of survey domains. Accordingly, a domain in northwestern $\mathrm{MB}$ bounded by $55^{\circ}$ to $60^{\circ}$ north latitude and $100^{\circ}$ to $102^{\circ}$ west longitude was defined for a survey in 2006, and a domain in northcentral SK bounded by the Canadian Shield margin to 


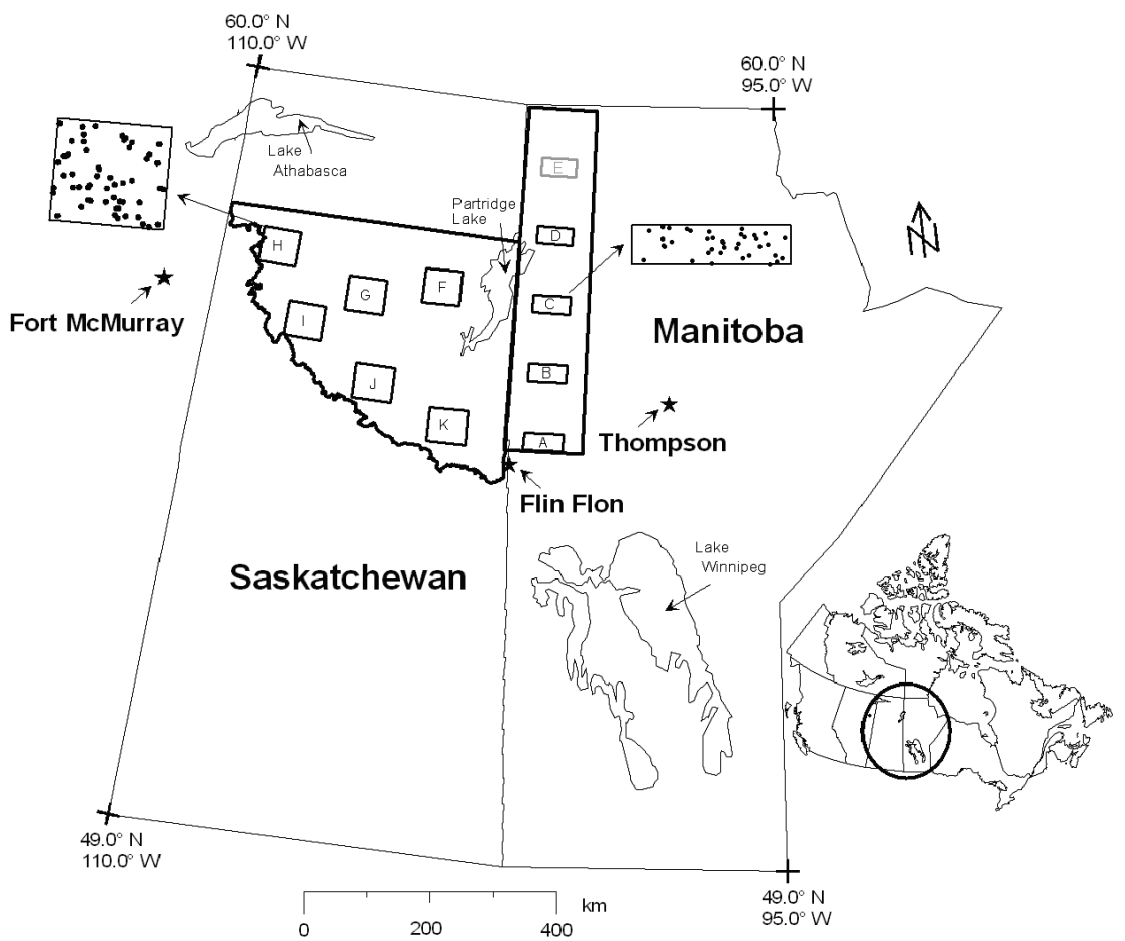

Fig. 1. The survey domains in northwestern MB and north-central SK are shown by the outlined polygons. The irregular southern boundary of the SK domain is also the southern boundary of the Canadian Shield. In MB, the Shield boundary continues southeast to Lake Winnipeg and then follows the eastern shore of the lake. Lake sampling occurred in all the lettered blocks except Block E. Examples of the locations of randomly selected lakes are shown for Blocks $\mathrm{C}$ and $\mathrm{H}$. Point sources of $\mathrm{S}$ and $\mathrm{N}$ emissions occur at Thompson and Flin Flon, MB, and at Fort, McMurray, AB west of SK.

the south and $58^{\circ}$ latitude to the north was defined for a survey in 2007 (Fig. 1). These domains cover a very large $\left(\sim 193,000 \mathrm{~km}^{2}\right)$ and very remote geographical area which necessitated the use of helicopters and fixed-wing aircraft to access the lakes. In order to minimize the logistical costs, 11 sampling blocks (blocks labelled A, B., etc. in Fig. 1) were defined assuming that they were representative of the overall domains. In the end, study budget constraints prevented sampling of the most northerly block (E) in MB.

\subsection{Lake inventories and sample lake selection}

A comprehensive, preferably digital inventory of lakes within the survey domains was needed to select a representative subset of sample lakes. Unfortunately, no such inventory existed for this part of MB or SK and we were obliged to create one. This was accomplished using GIS technology applied to the digital National Topographic Database (NTDB) at the 1:50,000 scale. The 1:50,000 topographic maps were stitched together into a single contiguous map and the boundaries inspected to identify and correct the minor discontinuities that arise during this process. Water body centroid coordinates, area (not including islands), plus other NTDB identifiers and polygon attributes were extracted for the entire survey domain and placed in separate databases and GIS shape-files. A unique random identification number was assigned to every database record, i.e. lake, using a Microsoft Access utility. Water bodies having centroid coordinates falling outside the geographic boundaries of the overall survey domains were not included in the inventories even though parts of them were within the boundaries. On 1:50,000 maps, water bodies with an area greater than $\sim 500 \mathrm{~m}^{2}(\sim 0.05$ ha) should be identifiable, and approximately half of the inventory records represented these extremely small lakes. Physically accessing such small water bodies, even by helicopter, can be problematic, however. We therefore decided to limit our target population (i.e., the one used to select sample lakes) to lakes $\geq 1$ ha.

The sampling blocks shown in figure 1 were composed of two adjacent 1:50,000 NTDB map units in MB and four adjacent map units in SK. The lake inventory information applicable to each of them was screened from the overall domain inventory by identifying all water bodies that had centroid coordinates within the block boundaries.

The scale of the sampling effort was very much constrained by the financial resources available for the field surveys such that we were able to visit 152 lakes in MB and 295 lakes in SK.

A stratified-random lake selection methodology similar to that of Henriksen et al. (1996) was used. The lake inventory records were screened into the eight size classes (strata) shown in table 1, and each one sorted according to their unique random identifier thereby providing a randomized list of lakes for each strata in each sampling block. Given the constraints on the total num- 
Tab. 1. Overall number of lakes $\geq 1$ ha and number in eight size classes identified in the survey domain and in 11 sampling blocks (see Fig. 1; block E was never sampled however). The cumulative lake area ( $\mathrm{km}^{2}$, excluding islands) is shown also. Note that sampling blocks $\mathrm{F}$ through $\mathrm{K}$ in SK are twice the geographic area of blocks A through $\mathrm{E}$ in MB.

\begin{tabular}{|c|c|c|c|c|c|c|c|c|c|c|}
\hline & \multirow{2}{*}{$\begin{array}{c}\text { Overall } \\
\text { n. of lakes }\end{array}$} & \multicolumn{8}{|c|}{ Size Class } & \multirow{2}{*}{$\begin{array}{c}\text { Overall area } \\
\left(\mathrm{km}^{2}\right)\end{array}$} \\
\hline & & $\begin{array}{c}>5000 \\
\text { (ha) }\end{array}$ & $\begin{array}{l}>500 \text { to } 5000 \\
\text { (ha) }\end{array}$ & $\begin{array}{l}>100 \text { to } 500 \\
\text { (ha) }\end{array}$ & $\begin{array}{c}>50 \text { to } 100 \\
\text { (ha) }\end{array}$ & $\begin{array}{l}>10 \text { to } 50 \\
\text { (ha) }\end{array}$ & $\begin{array}{c}>5 \text { to } 10 \\
\text { (ha) }\end{array}$ & $\begin{array}{c}>2 \text { to } 5 \\
\text { (ha) }\end{array}$ & $\begin{array}{c}\geq 1 \text { to } 2 \\
\text { (ha) }\end{array}$ & \\
\hline Domain & 81494 & 76 & 763 & 3632 & 4244 & 22201 & 14824 & 20634 & 15120 & 45285 \\
\hline A (MB) & 362 & 1 & 8 & 25 & 21 & 135 & 60 & 67 & 45 & 445 \\
\hline B (MB) & 280 & 1 & 6 & 18 & 18 & 85 & 45 & 64 & 43 & 187 \\
\hline $\mathrm{C}(\mathrm{MB})$ & 434 & 2 & 5 & 28 & 36 & 151 & 72 & 84 & 56 & 305 \\
\hline $\mathrm{D}(\mathrm{MB})$ & 586 & 0 & 12 & 47 & 34 & 168 & 102 & 119 & 104 & 271 \\
\hline E (MB) & 853 & 0 & 5 & 46 & 47 & 248 & 130 & 200 & 177 & 234 \\
\hline $\mathrm{F}(\mathrm{SK})$ & 1405 & 0 & 12 & 63 & 65 & 430 & 284 & 333 & 218 & 399 \\
\hline $\mathrm{G}(\mathrm{SK})$ & 2491 & 0 & 9 & 77 & 123 & 623 & 436 & 696 & 527 & 587 \\
\hline $\mathrm{H}(\mathrm{SK})$ & 1766 & 1 & 3 & 45 & 97 & 375 & 299 & 498 & 448 & 353 \\
\hline I (SK) & 1249 & 0 & 14 & 55 & 49 & 273 & 218 & 336 & 304 & 401 \\
\hline $\mathrm{J}(\mathrm{SK})$ & 1509 & 2 & 11 & 100 & 96 & 474 & 303 & 333 & 190 & 777 \\
\hline $\mathrm{K}(\mathrm{SK})$ & 1557 & 3 & 14 & 77 & 84 & 489 & 346 & 365 & 179 & 736 \\
\hline
\end{tabular}

ber of lakes to be sampled and the stratified lake inventories, the following process for lake selection was used. First, all lakes in the two largest size classes were selected for sampling because they have special economic value in terms of recreational use, biological diversity, etc. Second, the number of lakes to be sampled from each block was allocated in proportion to the blocks' respective lake densities. Third, within each block, the number of sample lakes for that block was distributed among the size classes in proportion to the average ratios of the number of lakes between size classes. Fourth, randomized selection was obtained by simply taking the appropriate number of lakes for each size class in each block from the top of the randomized lists. Finally, the selected lakes were individually checked to determine whether special factors such as association with mining operations, settlements, or near power lines rendered them undesirable choices. In the six cases where a lake was discarded, the next unused record in the randomized list was substituted.

\subsection{Sample collection, processing and chemical analysis}

We visited the lakes in mid to late September in expectation that fall overturn would have occurred thereby yielding mixed water-column samples. In reality, this was a little early since a few lakes were still thermally stratified. However, most lakes were shallow and well-mixed, and it is unlikely that the limited number of stratified cases significantly affect the acidification evaluation presented here.

At a visually defined, mid-lake position selected during helicopter approach, physical measurements (water depth, Secchi depth, and a thermal profile) were recorded, and a two litre bulk sample collected from one meter below the surface. After returning to a field laboratory, $\mathrm{pH}$ and specific conductance were measured and the bulk sample was sub-divided and processed (i.e., filtered, preserved, etc. as required for the chemical analyses to be conducted on that sub-sample) into ali- quots for major ion, nutrient and metal analyses. The aliquots were express shipped on ice to the water chemistry laboratory at the Great Lakes Forestry Centre (GLFC) in Sault Ste Marie, Ontario where chemical analyses were performed as soon as possible (immediately for perishable nutrient parameters). The GLFC laboratory uses standard methods for all chemical parameters and participates in national QA-QC programs to assure production of high quality chemical analyses. We also use charge balance calculations to independently verify the data quality.

\subsection{Critical load and exceedance calculations}

The Steady-State Water Chemistry Model (SSWC) was used to calculate CL of acidity (expressed as eq ha ${ }^{-1}$ $\mathrm{y}^{-1}$ ) for the survey lakes (Henriksen et al. 2002; UNECE 2004). The SSWC employs an alkalinity threshold called $\mathrm{ANC}_{\text {limit }}$ to define the onset of significant harmful effects, most commonly loss of fish populations. Values for $\mathrm{ANC}_{\text {limit }}$ have ranged from $20 \mu \mathrm{eq} \mathrm{L} \mathrm{L}^{-1}$ (Lien et al. 1996) through $40 \mu \mathrm{eq} \mathrm{L} \mathrm{L}^{-1}$ (Henriksen et al. 2002) to $75 \mu \mathrm{eq} \mathrm{L}^{-1}$ (WRS 2004). The SSWC as originally formulated did not explicitly consider the influence of natural organic acids when calculating $\mathrm{CL}$; however, this will be important for our DOC-rich sample population (see discussion). Lydersen et al. (2004) showed that the fit between Norwegian fish status and ANC improved when an organic acid adjusted ANC was used. This led UNECE (2004) to recommend that the Lydersen et al. (2004) relationship be used to estimate $\mathrm{ANC}_{\text {limit }}$ on a lake-by-lake basis in waters with higher DOC levels. Here we have used $\mathrm{ANC}_{\text {limit }}=10+$ $(10.2 / 3) \times$ DOC) where DOC is in $\mathrm{mg} \mathrm{L}^{-1}$ (J. Aherne, pers. comm.).

In addition to lake water chemistry and the $\mathrm{ANC}_{\text {limit }}$, the SSWC requires a value for two other variables. First, runoff is needed to convert concentrations into chemical fluxes. Here we used lake specific runoff values estimated by Gibson et al. (2010, this issue) using the Isotope Mass Balance Model (IMB). Second, the 
Tab. 2. Number of sample lakes in each sampling block, plus range, mean $(\mathrm{Mn})$ and standard deviation (SD) for water column depth $(\mathrm{m})$ at the mid-lake sampling point, Secchi depth $(\mathrm{m})$, and field-measured $\mathrm{pH}$ and specific conductance $\left(\mu \mathrm{S} \mathrm{cm}^{-1}\right)$.

\begin{tabular}{|c|c|c|c|c|c|c|c|c|c|c|c|c|c|}
\hline \multirow[b]{2}{*}{ Block } & \multirow[b]{2}{*}{$\mathrm{n}$} & \multicolumn{3}{|c|}{$\begin{array}{l}\text { Mid-lake Depth } \\
(\mathrm{m})\end{array}$} & \multicolumn{3}{|c|}{$\begin{array}{l}\text { Secchi Depth } \\
\text { (m) }\end{array}$} & \multicolumn{3}{|c|}{$\mathrm{pH}$} & \multicolumn{3}{|c|}{$\begin{array}{l}\text { Specific Conductance } \\
\qquad\left(\mu \mathrm{S} \mathrm{cm}^{-1}\right)\end{array}$} \\
\hline & & Range & $\mathrm{Mn}$ & SD & Range & $\mathrm{Mn}$ & SD & Range & $\mathrm{Mn}$ & SD & Range & $\mathrm{Mn}$ & SD \\
\hline A & 30 & $0.5-32.5$ & 5.3 & 6.9 & $0.3-4.5$ & 1.6 & 1.0 & $5.7-8.4$ & 7.2 & 0.6 & $18-131$ & 62 & 33 \\
\hline B & 30 & $0.7-34.2$ & 4.8 & 6.5 & $0.3-4.0$ & 1.6 & 0.8 & $5.4-8.0$ & 7.1 & 0.5 & $16-138$ & 52 & 38 \\
\hline $\mathrm{C}$ & 40 & $0.3-14.3$ & 4.2 & 2.8 & $0.3-7.0$ & 1.8 & 1.4 & $5.6-7.5$ & 6.8 & 0.4 & $6-34$ & 20 & 5.6 \\
\hline D & 52 & $0.4-11.4$ & 3.1 & 2.2 & $0.3-9.0$ & 1.8 & 1.3 & $5.2-7.5$ & 6.8 & 0.6 & $6-31$ & 19 & 6.1 \\
\hline $\mathrm{F}$ & 38 & $0.9-20.1$ & 4.1 & 4.3 & $0.5-7.5$ & 2.3 & 1.6 & $5.6-7.1$ & 6.7 & 0.4 & $9-35$ & 23 & 6.8 \\
\hline G & 68 & $0.6-31.2$ & 5.4 & 5.7 & $0.8-6.0$ & 2.7 & 1.6 & $4.7-7.5$ & 6.6 & 0.6 & $5-57$ & 18 & 10 \\
\hline $\mathrm{H}$ & 51 & $0.5-25.1$ & 5.8 & 5.3 & $0.5-6.0$ & 2.9 & 1.5 & $4.3-7.5$ & 6.6 & 0.7 & $6-49$ & 21 & 9.0 \\
\hline I & 43 & $0.5-18.1$ & 4.5 & 5.0 & $0.5-6.3$ & 2.3 & 1.3 & $5.1-7.8$ & 6.9 & 0.5 & 15-92 & 34 & 16 \\
\hline $\mathrm{J}$ & 46 & $1.6-32.3$ & 9.0 & 7.1 & $0.5-5.3$ & 2.2 & 1.3 & $4.8-8.4$ & 6.7 & 0.7 & $12-156$ & 41 & 28 \\
\hline K & 49 & $0.6-26.0$ & 6.8 & 5.8 & $0.5-5.0$ & 1.9 & 1.0 & $6.0-8.3$ & 7.1 & 0.5 & $23-136$ & 48 & 27 \\
\hline
\end{tabular}

value for the so-called $F$-factor (which relates the present-day excess production of base cations $(\mathrm{Cb})$ from catchment soils to the long-term changes in inputs of non-marine acid anions) was estimated using the equation suggested by Brakke et al. (1990).

The CL exceedance is calculated as acidifying deposition minus the CL and can be either positive or negative. A negative exceedance value implies that the lake is not presently being harmed by acidic deposition within the confines of the $\mathrm{ANC}_{\text {limit }}$ used to calculate the $\mathrm{CL}$. All $\mathrm{S}$ deposition is assumed to be acidifying so that Total $\mathrm{S}$ deposition (expressed as $\mathrm{SO}_{4}{ }^{2-}$ deposition) is used in the exceedance calculation. Jeffries \& Ouimet (2005) suggested that the role of $\mathrm{N}$ deposition in the CL exceedance be considered in two ways.

First, the present-day contribution of $\mathrm{N}$ deposition to the exceedance is reflected in the $\mathrm{NO}_{3}{ }^{-}$flux leaving a lake. Hence:

$$
\begin{gathered}
\mathrm{N} \text {-leaching exceedance }= \\
=\text { Total } \mathrm{S} \text { deposition }+\mathrm{NO}_{3}^{-} \text {leached }-\mathrm{CL}
\end{gathered}
$$

The $\mathrm{NO}_{3}^{-}$leached is estimated as the product of the lake $\mathrm{NO}_{3}^{-}$concentration and runoff. Second, if all N deposition becomes acidifying then an estimate of total $\mathrm{N}$ deposition can be used directly to calculate the socalled Steady-state exceedance:

$$
\begin{gathered}
\text { Steady-state exceedance }= \\
=\text { Total } \mathrm{S} \text { deposition }+ \text { Total } \mathrm{N} \text { deposition }-\mathrm{CL}
\end{gathered}
$$

This would be the situation if the lake ecosystem became nitrogen saturated and all $\mathrm{N}$ inputs were mobile in the same way as is assumed for $\mathrm{S}$ inputs. The two exceedance values are used to bound the possible range.

The total (wet plus dry) $\mathrm{S}$ and $\mathrm{N}$ deposition values used here to calculate exceedances were interpolated on a lake-by-lake basis from the gridded output of a run of the AURAMS (A Unified Regional Air-quality Modelling System) model (Moran et al. 2008). It used 2002 North American $\mathrm{S}$ and $\mathrm{N}$ emissions as model input which we have assumed reflect the current situation. AURAMS simulates near-source as well as regional deposition so that the higher local deposition associated with the smelter and oil sands sources is apparent.

\section{RESULTS}

\subsection{Water chemistry}

The distribution of the number of lakes among the eight size classes for the overall (MB + SK) survey domain and the individual sampling blocks is given in table 1 . The overall domain contains 81,494 lakes $\geq 1$ ha in area corresponding to a landscape lake density of 0.42 lakes per $\mathrm{km}^{2}$ and a total lake area of $45,285 \mathrm{~km}^{2}$. The lakes in our inventory cover $>23 \%$ of the domain surface area, and this does not count the area associated with rivers. As expected, small lakes dominate the inventory in terms of numbers; $62 \%$ of the lakes are $\leq 10$ ha in area. Large lakes ( $>5000 \mathrm{ha}$ ) are few in number (just 76 which includes Reindeer Lake on the MB-SK border $-a$ quasi "Great Lake" shown on figure 1 with an area of $565,800 \mathrm{ha}$ ), but they constitute $29 \%$ of the overall lake area.

Among the sample blocks, lake density ranged from 0.17 lakes per $\mathrm{km}^{2}$ (Block B) to 0.78 lakes per $\mathrm{km}^{2}$ (Block $\mathrm{G}$ ) which accounts for the block-to-block differences in the number of selected sample lakes (Tab. 2). In the MB survey domain, lake density tends to be greater in the north compared to the south. The central part of the SK survey domain (represented by Block G) contains the highest lake density.

Selected measurements made during the lake visit or shortly thereafter in the field laboratory are summarized in table 2. There was no opportunity to survey the lakes' bathymetries, so we can only use the depth measured at the mid-lake sampling point as an indicator of lake depth. The broad range in mid-lake depth observed in all blocks reflects the broad range in the size of sample lakes, i.e. larger lakes tend to be deeper although note that the largest lake was also the deepest in only one Block (B), and in Block D, the deepest lake was only 37 ha in area. Overall, the sample lakes tended to be shallow which probably explains why so few of them were thermally stratified even though surface water temperatures were usually $>4{ }^{\circ} \mathrm{C}$, i.e., they are routinely mixed by wind. Mean mid-lake depth ranged from 3.1 to $9.0 \mathrm{~m}$ with Blocks $\mathrm{J}$ and $\mathrm{K}$ (the most southerly Blocks in the SK domain) having the greatest mean depth. 
Tab. 3. Statistics determined for selected lake chemistry variables for the 10 sampling blocks surveyed in 2006 and 2007. Similar statistics are provided for three other recent surveys in the same general region (see text). *: Vale Inco Ltd. $2006 / 07$ surveys (UMA 2007a, 2008); 2 anomalous Total N values excluded; ${ }^{\dagger}$ : Hudson Bay Mining and Smelting Co. Ltd. 2006 survey (UMA 2007b); 1 Total Al excluded; *: Saskatchewan Ministry of Environment 2007 and 2008 surveys (Scott et al. 2010, this issue).

\begin{tabular}{|c|c|c|c|c|c|c|c|c|c|c|c|c|c|c|}
\hline \multirow{2}{*}{\multicolumn{2}{|c|}{ Variable }} & \multicolumn{10}{|c|}{ Sampling Block } & \multicolumn{3}{|c|}{ Other Surveys } \\
\hline & & $\mathrm{A}$ & B & $\mathrm{C}$ & $\mathrm{D}$ & $\mathrm{F}$ & $\mathrm{G}$ & $\mathrm{H}$ & I & $\mathrm{J}$ & $\mathrm{K}$ & $\mathrm{VI}^{*}$ & $\mathrm{HB}^{\dagger}$ & $\mathrm{SE}^{\ddagger}$ \\
\hline $\begin{array}{c}\mathrm{Cb} \\
\left(\mu \mathrm{eq} \mathrm{L} \mathrm{L}^{-1}\right)\end{array}$ & $\begin{array}{c}\text { Min } \\
\text { Max } \\
\text { Mean } \\
\text { SD }\end{array}$ & $\begin{array}{c}182 \\
1462 \\
681 \\
378\end{array}$ & $\begin{array}{c}169 \\
1551 \\
575 \\
429\end{array}$ & $\begin{array}{c}54 \\
407 \\
229 \\
71\end{array}$ & $\begin{array}{c}48 \\
346 \\
202 \\
66\end{array}$ & $\begin{array}{c}67 \\
459 \\
244 \\
75\end{array}$ & $\begin{array}{c}31 \\
595 \\
189 \\
107\end{array}$ & $\begin{array}{c}56 \\
521 \\
233 \\
99\end{array}$ & $\begin{array}{l}168 \\
980 \\
375 \\
169\end{array}$ & $\begin{array}{c}66 \\
1724 \\
431 \\
297\end{array}$ & $\begin{array}{c}249 \\
1545 \\
516 \\
270\end{array}$ & $\begin{array}{c}223 \\
2962 \\
1028 \\
644\end{array}$ & $\begin{array}{c}145 \\
9687 \\
1635 \\
1736\end{array}$ & $\begin{array}{c}64 \\
2621 \\
293 \\
339\end{array}$ \\
\hline $\begin{array}{c}\text { Alk } \\
\left(\mu \mathrm{eq} \mathrm{L} \mathrm{L}^{-1}\right)\end{array}$ & $\begin{array}{c}\text { Min } \\
\text { Max } \\
\text { Mean } \\
\text { SD }\end{array}$ & $\begin{array}{c}20 \\
1255 \\
467 \\
360\end{array}$ & $\begin{array}{c}12 \\
1373 \\
420 \\
417\end{array}$ & $\begin{array}{c}11 \\
241 \\
112 \\
51\end{array}$ & $\begin{array}{c}4 \\
210 \\
113 \\
61\end{array}$ & $\begin{array}{c}14 \\
252 \\
139 \\
72\end{array}$ & $\begin{array}{l}-17 \\
538 \\
126 \\
105\end{array}$ & $\begin{array}{c}11 \\
429 \\
137 \\
91\end{array}$ & $\begin{array}{c}23 \\
881 \\
241 \\
181\end{array}$ & $\begin{array}{c}-3 \\
1496 \\
242 \\
287\end{array}$ & $\begin{array}{c}61 \\
1285 \\
333 \\
284\end{array}$ & $\begin{array}{c}97 \\
2411 \\
906 \\
633\end{array}$ & $\begin{array}{c}76 \\
10100 \\
1516 \\
1808\end{array}$ & $\begin{array}{c}-2 \\
2608 \\
241 \\
355\end{array}$ \\
\hline $\begin{array}{c}\text { ANC } \\
\left(\mu \mathrm{eq} \mathrm{L} \mathrm{L}^{-1}\right)\end{array}$ & $\begin{array}{c}\text { Min } \\
\text { Max } \\
\text { Mean } \\
\text { SD }\end{array}$ & $\begin{array}{c}135 \\
1425 \\
608 \\
379\end{array}$ & $\begin{array}{c}143 \\
1529 \\
541 \\
437\end{array}$ & $\begin{array}{c}39 \\
379 \\
203 \\
69\end{array}$ & $\begin{array}{c}19 \\
317 \\
173 \\
63\end{array}$ & $\begin{array}{c}28 \\
449 \\
221 \\
76\end{array}$ & $\begin{array}{c}6 \\
545 \\
163 \\
103\end{array}$ & $\begin{array}{c}35 \\
465 \\
198 \\
94\end{array}$ & $\begin{array}{l}147 \\
938 \\
332 \\
170\end{array}$ & $\begin{array}{c}141 \\
1553 \\
375 \\
284\end{array}$ & $\begin{array}{c}198 \\
1197 \\
435 \\
243\end{array}$ & $\begin{array}{c}101 \\
2418 \\
967 \\
600\end{array}$ & $\begin{array}{c}117 \\
9673 \\
1515 \\
1672\end{array}$ & $\begin{array}{c}-10 \\
2003 \\
240 \\
282\end{array}$ \\
\hline $\begin{array}{c}\mathrm{SO}_{4}{ }^{2-} \\
\left(\mu \mathrm{eq} \mathrm{L}^{-1}\right)\end{array}$ & $\begin{array}{c}\text { Min } \\
\text { Max } \\
\text { Mean } \\
\text { SD }\end{array}$ & $\begin{array}{c}5 \\
135 \\
53 \\
137\end{array}$ & $\begin{array}{c}3 \\
76 \\
23 \\
17\end{array}$ & $\begin{array}{c}5 \\
32 \\
16 \\
6\end{array}$ & $\begin{array}{c}4 \\
53 \\
15 \\
9\end{array}$ & $\begin{array}{c}3 \\
37 \\
14 \\
7\end{array}$ & $\begin{array}{c}2 \\
73 \\
15 \\
9\end{array}$ & $\begin{array}{c}2 \\
42 \\
17 \\
9\end{array}$ & $\begin{array}{c}1 \\
107 \\
22 \\
17\end{array}$ & $\begin{array}{c}3 \\
396 \\
60 \\
68\end{array}$ & $\begin{array}{c}8 \\
178 \\
49 \\
27\end{array}$ & $\begin{array}{c}1 \\
492 \\
20 \\
63\end{array}$ & $\begin{array}{c}1 \\
241 \\
33 \\
40\end{array}$ & $\begin{array}{l}1 \\
68 \\
20 \\
12\end{array}$ \\
\hline $\begin{array}{c}\mathrm{Cl}^{-} \\
\left(\mu \mathrm{eq} \mathrm{L} \mathrm{L}^{-1}\right)\end{array}$ & $\begin{array}{c}\text { Min } \\
\text { Max } \\
\text { Mean } \\
\text { SD }\end{array}$ & $\begin{array}{c}2 \\
19 \\
8 \\
4\end{array}$ & $\begin{array}{c}1 \\
13 \\
5 \\
3\end{array}$ & $\begin{array}{l}1 \\
6 \\
4 \\
1\end{array}$ & $\begin{array}{c}3 \\
14 \\
5 \\
2\end{array}$ & $\begin{array}{l}1 \\
9 \\
5 \\
2\end{array}$ & $\begin{array}{c}2 \\
14 \\
5 \\
3\end{array}$ & $\begin{array}{c}2 \\
55 \\
9 \\
9\end{array}$ & $\begin{array}{c}2 \\
103 \\
10 \\
16\end{array}$ & $\begin{array}{c}2 \\
60 \\
11 \\
13\end{array}$ & $\begin{array}{c}1 \\
54 \\
15 \\
14\end{array}$ & $\begin{array}{c}4 \\
291 \\
20 \\
38\end{array}$ & $\begin{array}{c}5 \\
948 \\
43 \\
136\end{array}$ & $\begin{array}{c}1 \\
573 \\
20 \\
63\end{array}$ \\
\hline $\begin{array}{c}\mathrm{DOC} \\
\left(\mathrm{mg} \mathrm{L}^{-1}\right)\end{array}$ & $\begin{array}{c}\text { Min } \\
\text { Max } \\
\text { Mean } \\
\text { SD }\end{array}$ & $\begin{array}{c}8.8 \\
38.4 \\
20.6 \\
8.3\end{array}$ & $\begin{array}{c}7.1 \\
30.9 \\
16.2 \\
5.7\end{array}$ & $\begin{array}{c}2.9 \\
26.5 \\
12.1 \\
5.5\end{array}$ & $\begin{array}{c}1.9 \\
23.3 \\
9.7 \\
4.8\end{array}$ & $\begin{array}{c}3.4 \\
26.6 \\
10.3 \\
5.7\end{array}$ & $\begin{array}{c}1.7 \\
19.9 \\
6.8 \\
3.9\end{array}$ & $\begin{array}{c}1.7 \\
32.4 \\
9.2 \\
6.6\end{array}$ & $\begin{array}{c}3.5 \\
27.6 \\
13.0 \\
5.4\end{array}$ & $\begin{array}{c}4.0 \\
30.2 \\
14.6 \\
6.5\end{array}$ & $\begin{array}{c}6.5 \\
23.6 \\
14.9 \\
4.1\end{array}$ & $\begin{array}{c}7.0 \\
36.0 \\
19.1 \\
6.9\end{array}$ & $\begin{array}{c}3.7 \\
39.7 \\
15.2 \\
7.7\end{array}$ & $\begin{array}{c}1.3 \\
25.3 \\
6.5 \\
4.0\end{array}$ \\
\hline $\begin{array}{l}\text { Total Al } \\
\left(\mu \mathrm{g} \mathrm{L}^{-1}\right)\end{array}$ & $\begin{array}{c}\text { Min } \\
\text { Max } \\
\text { Mean } \\
\text { SD }\end{array}$ & $\begin{array}{c}5 \\
352 \\
85 \\
90\end{array}$ & $\begin{array}{c}11 \\
242 \\
76 \\
62\end{array}$ & $\begin{array}{c}6 \\
271 \\
71 \\
65\end{array}$ & $\begin{array}{c}5 \\
142 \\
32 \\
35\end{array}$ & $\begin{array}{c}6 \\
279 \\
48 \\
57\end{array}$ & $\begin{array}{c}<5 \\
133 \\
23 \\
30\end{array}$ & $\begin{array}{c}<5 \\
177 \\
28 \\
36\end{array}$ & $\begin{array}{c}5 \\
225 \\
45 \\
48\end{array}$ & $\begin{array}{c}7 \\
481 \\
124 \\
142\end{array}$ & $\begin{array}{c}5 \\
483 \\
97 \\
107\end{array}$ & $\begin{array}{c}<20 \\
450 \\
80 \\
100\end{array}$ & $\begin{array}{c}<20 \\
3350 \\
151 \\
435\end{array}$ & $\begin{array}{c}<10 \\
125 \\
16 \\
22\end{array}$ \\
\hline $\begin{array}{l}\text { Total P } \\
\left(\mu \mathrm{g} \mathrm{L}^{-1}\right)\end{array}$ & $\begin{array}{c}\text { Min } \\
\text { Max } \\
\text { Mean } \\
\text { SD }\end{array}$ & $\begin{array}{c}7 \\
48 \\
18 \\
7\end{array}$ & $\begin{array}{c}8 \\
45 \\
19 \\
9\end{array}$ & $\begin{array}{c}7 \\
66 \\
22 \\
12\end{array}$ & $\begin{array}{c}5 \\
83 \\
17 \\
13\end{array}$ & $\begin{array}{c}4 \\
32 \\
12 \\
6\end{array}$ & $\begin{array}{c}5 \\
49 \\
14 \\
9\end{array}$ & $\begin{array}{c}1 \\
70 \\
17 \\
11\end{array}$ & $\begin{array}{c}5 \\
36 \\
14 \\
6\end{array}$ & $\begin{array}{c}4 \\
31 \\
12 \\
6\end{array}$ & $\begin{array}{c}6 \\
51 \\
19 \\
10\end{array}$ & $\begin{array}{c}5 \\
92 \\
18 \\
15\end{array}$ & $\begin{array}{c}3 \\
162 \\
24 \\
25\end{array}$ & $\begin{array}{c}2 \\
102 \\
18 \\
17\end{array}$ \\
\hline $\begin{array}{c}\text { Total N } \\
\left(\mathrm{mg} \mathrm{L}^{-1}\right)\end{array}$ & $\begin{array}{c}\text { Min } \\
\text { Max } \\
\text { Mean } \\
\text { SD }\end{array}$ & $\begin{array}{l}0.39 \\
1.40 \\
0.77 \\
0.26\end{array}$ & $\begin{array}{l}0.28 \\
1.16 \\
0.56 \\
0.21\end{array}$ & $\begin{array}{l}0.23 \\
0.78 \\
0.43 \\
0.13\end{array}$ & $\begin{array}{l}0.19 \\
1.33 \\
0.47 \\
0.19\end{array}$ & $\begin{array}{l}0.15 \\
0.97 \\
0.43 \\
0.17\end{array}$ & $\begin{array}{l}0.15 \\
1.18 \\
0.37 \\
0.18\end{array}$ & $\begin{array}{l}0.11 \\
1.79 \\
0.46 \\
0.29\end{array}$ & $\begin{array}{l}0.16 \\
1.11 \\
0.51 \\
0.23\end{array}$ & $\begin{array}{l}0.23 \\
1.41 \\
0.51 \\
0.25\end{array}$ & $\begin{array}{l}0.23 \\
1.25 \\
0.54 \\
0.18\end{array}$ & $\begin{array}{l}0.40 \\
5.73 \\
0.97 \\
0.81\end{array}$ & $\begin{array}{l}0.20 \\
2.60 \\
0.75 \\
0.40\end{array}$ & $\begin{array}{l}0.09 \\
2.83 \\
0.50 \\
0.33\end{array}$ \\
\hline
\end{tabular}

Water transparency as reflected in the Secchi Depth measurements (Tab. 2) is variable as shown by the broad ranges, but on average is very limited. Mean Secchi depths ranged from 1.6 to $2.9 \mathrm{~m}$ across the sampling blocks. The poor light penetration occurring in these lakes is most likely due to substantial DOC concentrations (see discussion).

The mean $\mathrm{pH}$ (Tab. 2) is typical of Shield lakes located in areas receiving little acidic deposition. $\mathrm{A} \mathrm{pH}$ of 6.0 has been commonly suggested in acidification assessments as a threshold for biological impairment of aquatic ecosystems (Baker et al. 1990; Jeffries et al. 2005). Here the observed minimum $\mathrm{pH}$ values (ranging from 4.3 to 6.0 ; nine of the 10 blocks had minimum $\mathrm{pH}$ $<6.0$ ) are principally due to dissociation of natural organic acids in combination with low $\mathrm{Cb}$. Both the $\mathrm{MB}$ and SK data sets show statistically significant, negative linear relationships between $\mathrm{pH}$ and DOC ( $p=0.022$ and $p<0.001$ respectively).
An indicator of lake sensitivity is the specific conductance statistics presented in table 2. Situated within the sparingly soluble silicate geology that characterizes much of the Canadian Shield, the lakes have relatively low dissolved ion concentrations that are reflected in their specific conductance values. In particular, the statistics for Blocks $\mathrm{C}$ through $\mathrm{H}$ in table 2 show that some of their sample lakes have very low specific conductance, e.g., minimum values $<10 \mu \mathrm{S} \mathrm{cm}^{-1}$. These lakes should be very sensitive to atmospheric inputs of strong acids and they will probably greatly influence the critical loads determined for those blocks.

Concentration statistics for selected major element variables plus Total $\mathrm{Al}, \mathrm{P}$ and $\mathrm{N}$ measured in our samples are presented in table 3 . The calculated variable ANC ( $\mathrm{Cb}$ minus the sum of acid anions) is also given in table 3. Analysis of variance for $\mathrm{pH}, \mathrm{Cb}, \mathrm{Alk}, \mathrm{SO}_{4}{ }^{2-}$ and DOC showed that significant between-block variance exists for all of them $(p<0.001$ in all cases). 


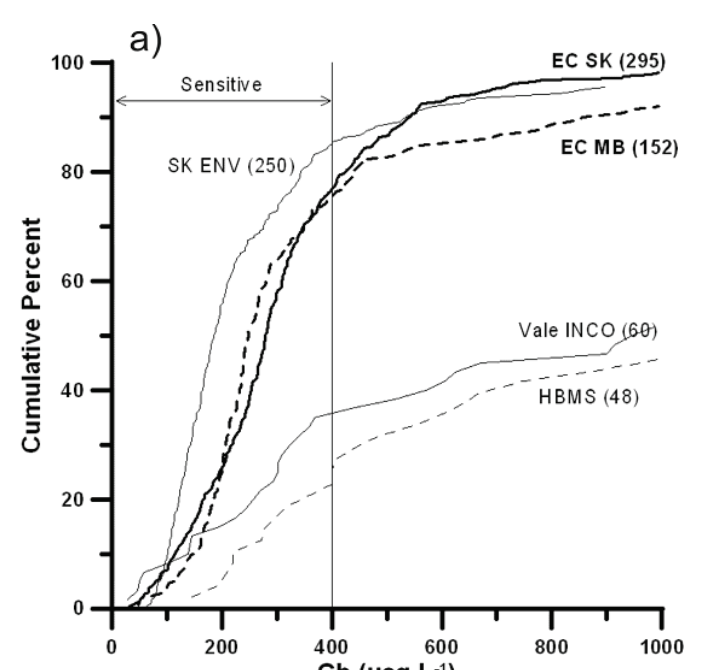

b)

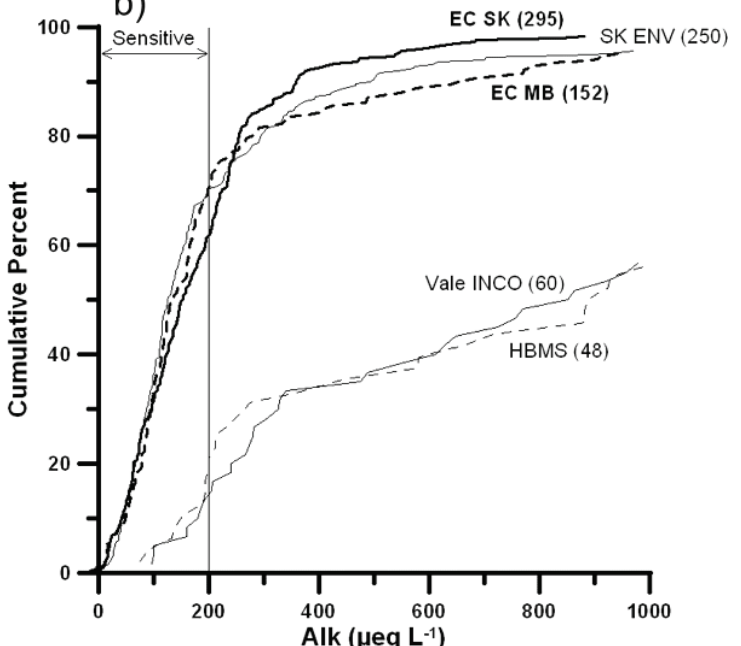

c)

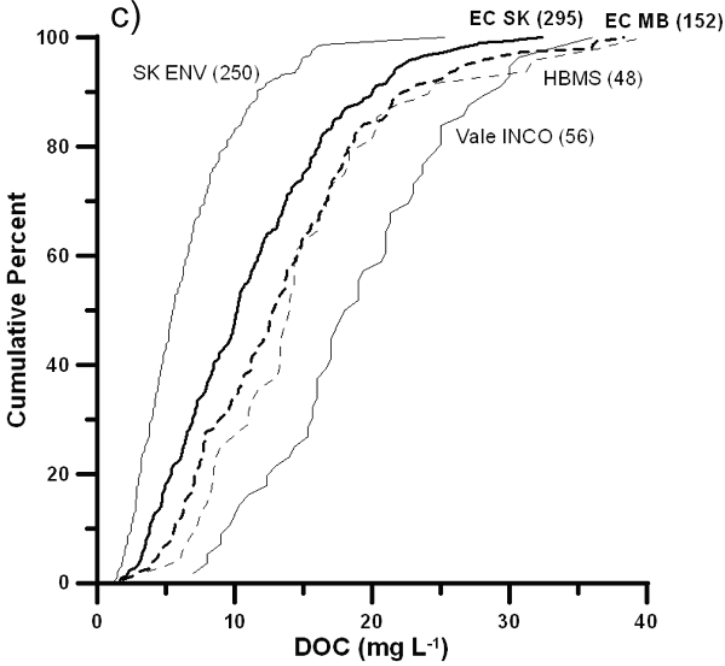

Fig. 2. Cumulative frequency distributions for (a) the sum of base cations $\left(\mathrm{Cb}, \mu \mathrm{eq} \mathrm{L}^{-1}\right)$, (b) Gran Alkalinity $\left(\mu \mathrm{eq} \mathrm{L}^{-1}\right)$ and (c) DOC $\left(\mathrm{mg} \mathrm{L}^{-1}\right)$. Concentration distributions for our MB and SK sample lakes are shown by the heavy dashed and solid lines respectively. The other distributions are for other recent surveys conducted in the same region (see the footnotes to Tabs 3 and 4).
Cumulative frequency distributions for $\mathrm{Cb}\left(\mathrm{Ca}^{2+}+\right.$ $\left.\mathrm{Mg}^{2+}+\mathrm{Na}^{+}+\mathrm{K}^{+}\right)$are presented in figure 2a. Lakes from all blocks were grouped by province to produce these distributions. Base cations present in a lake originate from either mineral weathering in the terrestrial catchment or atmospheric deposition. High $\mathrm{Cb}$ concentrations generally reflect rapid weathering, and therefore little sensitivity to acidic deposition (weathering is an acid consuming process). Such lakes have high CL values. The minimum $\mathrm{Cb}$ concentrations reported in table 3 show sensitive lakes in all the sampling blocks, although as suggested by the mean concentrations, Blocks $\mathrm{C}$ through $\mathrm{H}$ have the highest proportions of

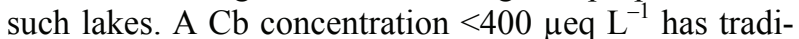
tionally been used as an indicator of acid sensitivity (Jeffries et al. 2005). Figure 2a suggests that $\sim 75 \%$ of our MB and SK sample lakes may be considered sensitive to acidification.

Both table 3 and figure 2 contain information from three other recent surveys conducted in the same region. In 2006, Vale Inco Ltd. (VI) who operates a nickel smelter at Thompson, MB (see Fig. 1) commissioned UMA Engineering Ltd. to conduct a survey of 50 lakes within roughly a $300 \mathrm{~km}$ radius of Thompson (UMA 2007a). Ten lakes further south were added the following year (UMA 2008). The sampling protocol involved access using fixed wing aircraft meaning that only lakes greater than 75 to 100 ha in area could be sampled. Hudson Bay Mining and Smelting Ltd. (HBMS) who operates a copper smelter at Flin Flon, MB also commissioned UMA Engineering Ltd. in 2006 to conduct a similar survey of 50 lakes surrounding its smelter (UMA 2007b). The third survey of 250 lakes was conducted in 2007 and 2008 by the SK Ministry of Environment (SK ENV; Scott et al. 2010, this issue) in the west central part of the province downwind of the rapidly expanding emissions produced by oil sand processing in the Fort McMurray area of AB. Sample lakes were selected randomly from alternating segments of a $300 \mathrm{~km}$ radial grid centred on Fort McMurray. Part of the radial grid, notably those segments closest to Fort McMurray, was off the Canadian Shield. Lake access was achieved by helicopter so that a broad range of lake sizes was sampled.

Mean $\mathrm{Cb}$ concentrations measured by the VI and HBMS surveys (1028 and $1635 \mu \mathrm{eq} \mathrm{L}^{-1}$ respectively) are much higher than ours (minimum values are comparable) although the data for Blocks $\mathrm{A}, \mathrm{B}$ and $\mathrm{K}$ where some survey overlaps occurred do show our highest mean $\mathrm{Cb}$ concentrations in table 3. The difference between the VI-HBMS Cb data and ours is due to two factors: first, VI-HBMS sampling was focused in the somewhat less sensitive terrain that surrounds the smelters, and second, small lakes were excluded. The cumulative frequency distribution for $\mathrm{Cb}$ (Fig. 2a) clearly shows how much the VI and HBMS survey results differed from ours, i.e. $<40 \%$ of their sample 
populations are sensitive to acidification compared to $75 \%$ of ours. Conversely, the SK ENV survey which had a large degree of spatial overlap with Blocks H, I and to a lesser extent $\mathrm{G}$ showed $\mathrm{Cb}$ statistics (Tab. 3) and a cumulative frequency distribution (Fig. 2a) that are very similar to ours, lending credence to the results of both surveys. The higher maximum $\mathrm{Cb}$ concentration found by the SK ENV survey is due to the off-Shield sampling that occurred near the SK-AB border.

Gran Alkalinity statistics (Tab. 3) and cumulative frequency distribution (Fig. 2b) provide the same information as $\mathrm{Cb}$. Note that negative values for Alk were recorded in Blocks $\mathrm{G}$ and $\mathrm{J}$ and by the SK ENV survey. Negative Alk defines a lake as acidic. It was caused here by the occurrence of natural organic acidity in combination with extremely low $\mathrm{Cb}$. Values for the calculated variable ANC were always higher than our Alk values because they do not include the influence of organic acidity.

Sulphate and $\mathrm{Cl}^{-}$are minor anions compared to Alk although there is evidence of some regional differences. For example, mean $\mathrm{SO}_{4}{ }^{2-}$ concentrations are higher in the blocks nearer the smelters, and the four SK blocks located nearest the Shield boundary ( $\mathrm{H}$ to $\mathrm{K}$ ) had slightly higher mean and substantially higher maximum $\mathrm{Cl}^{-}$levels, most likely due to the higher evaporative concentration that arises from the lower annual precipitation and runoff occurring to the west and south.

Dissolved organic carbon (a surrogate for natural organic acidity) was an important source of anions in many of our survey lakes. Organic anions constitute an important component of our chemical charge balance, on average $40 \%$ and $37 \%$ of the anion sum for the MB and SK lakes respectively. While there are some very clear, low DOC lakes as evidenced by the minimum values in table 3 , the mean and maximum DOC values show that many lakes have substantial and sometimes very high concentrations. The cumulative frequency distribution (Fig. 2c) shows this well. More than 50\% of the lakes in all the surveys (except the SK ENV survey) have more than $10 \mathrm{mg} \mathrm{L}^{-1}$ DOC. This is approximately double the median DOC concentration reported for all the eastern provinces by Jeffries et al. (2005).

There is a decreasing, east-to-west gradient in regional DOC concentrations across our study area. Vale Inco conducted the most eastern survey of the five shown in figure $2 \mathrm{c}$, and it clearly exhibited the highest DOC concentrations in its cumulative frequency distribution. The HBMS survey which had a greater spatial communality with our survey blocks showed a DOC distribution very similar to our MB survey. To the west, the DOC distribution from our SK survey is shifted to lower concentrations, and finally, the DOC distribution for the SK ENV survey, which focused its sampling even further west, exhibits an even greater shift to lower concentrations. Note however that this is where the spatial trend stops. Lakes that are yet further west, i.e., near
Fort McMurray (Fig. 1) and off the Shield, have much higher DOC concentrations (Jeffries et al. 2005). The existence of this DOC gradient across north-central MB and SK is probably related to a combination of terrain and climatic factors, i.e. more prevalent lowland/wetland terrain and somewhat greater annual precipitation to the east.

Ecosystem acidification mobilizes Al from drainage basin soils and bedrock thereby increasing lake water concentrations. This is important because labile, ionic Al species are toxic to fish (Poléo et al. 1997). We could not quantify labile Al within our sampling and analytical protocol; however, mean Total Al concentrations (Tab. 3) were $<100 \mu \mathrm{g} \mathrm{L}^{-1}$ for all sampling blocks except Block $\mathbf{J}$ - the same block that showed the lowest $\mathrm{pH}$ and Alk concentrations. Significant positive relationships $(p<0.001)$ existed between Total Al and DOC for both of the MB and SK data sets. Binding of ionic $\mathrm{Al}$ species to organic anions reduce their toxicity, so it is unlikely that $\mathrm{Al}$ toxicity is important in our survey lakes.

Other metals $(\mathrm{Cd}, \mathrm{Cu}, \mathrm{Ni}, \mathrm{Pb}$ and $\mathrm{Zn}$ ) were also measured but not shown in table 3. Most values for all metals except $\mathrm{Zn}$ were below analytical detection limits. Mean $\mathrm{Zn}$ concentrations were 54 and $65 \mu \mathrm{g} \mathrm{L}{ }^{-1}$ for the $\mathrm{MB}$ and SK data sets respectively. Blocks $\mathrm{A}$ and $\mathrm{K}$ were located closest to a smelter (the HBMS facility at Flin Flon, Fig. 1), but their metal concentrations were no higher than those measured in other, more distant blocks.

The mean Total P concentrations of our remote survey lakes were higher than expected and would result in a mesotrophic classification. On the other hand, soluble reactive $\mathrm{P}$ concentrations (measured only in the 2007 SK survey; mean $7.5 \mu \mathrm{g} \mathrm{L}^{-1}$ ) were much lower suggesting that a significant component of the Total $\mathrm{P}$ was organic $\mathrm{P}$. This was also the case for Total N. The inorganic forms of $\mathrm{N}\left(\mathrm{NO}_{3}{ }^{-}\right.$and $\left.\mathrm{NH}_{4}{ }^{+}\right)$were almost always undetectable in our survey samples, and hence, almost all the Total $\mathrm{N}$ existed in organic forms.

\subsection{Critical loads and exceedances}

Having been included as recommended methodology by UNECE (2004), the SSWC has been used extensively and successfully to calculate CL and influence emission reduction policy in Europe. This has also been the case in Canada (e.g., Henriksen et al. 2002; WRS 2004; Dupont et al. 2005; Jeffries \& Ouimet 2005). However, we have employed two modifications that distinguish its use here from those previous applications, namely consideration of the influence of DOC through the use of the Lydersen et al. (2004) equation to calculate $\mathrm{ANC}_{\text {limit, }}$, and substitution of lake-by-lake values for runoff derived using the IMB Model (Gibson et al. 2010, this issue) for long-term regional runoff values. This runoff substitution applied to both our survey lakes and those of SK ENV. 
Tab. 4. Statistics for the CL of acidity calculated using the SSWC for the 10 sampling blocks and three other recent surveys conducted in the same region. The $5^{\text {th }}$ percentile ${ }^{\&}$ value provides $95 \%$ ecosystem protection. The $95^{\text {th }}$ percentile N-leaching and Steady-state exceedances were calculated using modelled S and $\mathrm{N}$ deposition for 2002 (see text). ${ }^{\&}$ : the $5^{\text {th }}$ percentile is taken as the CL for a regional data set (Jeffries \& Ouimet 2005). *: Vale Inco Ltd. 2006 and 2007 surveys (UMA 2007a 2008). $\uparrow$ : Hudson Bay Mining and Smelting Co. Ltd. 2006 survey (UMA 2007b). \$: Saskatchewan Ministry of Environment 2007 and 2008 surveys (Scott et al. 2010, this volume).

\begin{tabular}{|c|c|c|c|c|c|c|c|c|}
\hline & & \multicolumn{5}{|c|}{$\begin{array}{l}\text { Critical Load } \\
\left(\text { eq ha }{ }^{-1} \mathrm{y}^{-1}\right)\end{array}$} & \multicolumn{2}{|c|}{$\begin{array}{c}95^{\text {th }} \text { Percentile } \\
\text { Exceedance }\left(\text { eq ha }{ }^{-1} \mathrm{y}^{-1}\right)\end{array}$} \\
\hline & & Min & Max & Mean & SD & $5^{\text {th }}$ Percentile & N-leaching & Steady-state \\
\hline \multirow{10}{*}{ 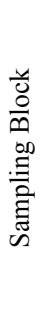 } & A & 3.4 & 1190 & 356 & 414 & 13.5 & 909 & 983 \\
\hline & B & 7.4 & 1370 & 400 & 340 & 25.4 & 156 & 208 \\
\hline & C & 2.3 & 706 & 176 & 176 & 8.5 & 95.0 & 138 \\
\hline & $\mathrm{D}$ & 1.2 & 2170 & 248 & 403 & 2.1 & 73.7 & 118 \\
\hline & $\mathrm{F}$ & 3.2 & 722 & 186 & 161 & 7.0 & 75.4 & 134 \\
\hline & G & -13.4 & 2600 & 193 & 383 & 4.2 & 86.2 & 171 \\
\hline & $\mathrm{H}$ & 0.2 & 1530 & 186 & 334 & 1.9 & 122 & 235 \\
\hline & I & 7.2 & 2040 & 365 & 388 & 52.7 & 54.5 & 172 \\
\hline & $\mathrm{J}$ & 0.5 & 1170 & 285 & 233 & 5.1 & 93.3 & 188 \\
\hline & $\mathrm{K}$ & 0.1 & 1310 & 321 & 284 & 44.3 & 174 & 259 \\
\hline \multirow{3}{*}{$\begin{array}{l}\frac{\omega}{0} \\
\stackrel{0}{0}\end{array}$} & $\mathrm{VI}^{*}$ & 181 & 4330 & 1400 & 1010 & 238 & -47.6 & 84.8 \\
\hline & $\mathrm{HB} \dagger$ & 171 & 10100 & 1730 & 1800 & 232 & -106 & -30.3 \\
\hline & SE† & 7.0 & 3380 & 341 & 426 & 27.1 & 79.9 & 202 \\
\hline
\end{tabular}

The Lydersen et al. (2004) $\mathrm{ANC}_{\text {limit }}$ values ranged from $14.4 \mu \mathrm{eq} \mathrm{L}^{-1}$ for a very clear, sensitive lake in SK $\left(\mathrm{DOC}=1.3 \mathrm{mg} \mathrm{L}^{-1} ; \mathrm{Cb}=162 \mu \mathrm{eq} \mathrm{L} \mathrm{L}^{-1}\right)$ to $145 \mu \mathrm{eq} \mathrm{L}$ for an extremely brown, insensitive lake, also in SK $\left(\mathrm{DOC}=39.7 \mathrm{mg} \mathrm{L}^{-1} ; \mathrm{Cb}=2660 \mu \mathrm{eq} \mathrm{L} \mathrm{L}^{-1}\right)$. The mean $\mathrm{ANC}_{\text {limit }}$ was $41 \mu \mathrm{eq} \mathrm{L}^{-1}$ in $\mathrm{SK}$ (very close to the value of 40 used by Henriksen et al. 2002; Dupont et al. 2005; and Jeffries \& Ouimet 2005); and $65 \mu \mathrm{eq} \mathrm{L}^{-1}$ in $\mathrm{MB}$, which was slightly less than the value of 75 used by WRS (2004) for high DOC lakes in AB.

The influence of substituting IMB runoff values for long-term regional values has been evaluated by Gibson et al. (2010, this issue). The IMB values tend to be lower and more variable than the regional values, causing the SSWC to yield lower and more variable CL.

SSWC CL results are presented in table 4. Minimum $\mathrm{CL}$ values for the sampling blocks are very close to zero (and even negative in one of the two cases that had negative Alk) implying that the most sensitive lakes in our survey are unable to accommodate any level of anthropogenic acidifying input. However, the range is broad, and the maximum CL (722 to $2600 \mathrm{eq} \mathrm{ha}^{-1} \mathrm{y}^{-1}$ ) are much higher than the $20 \mathrm{~kg}$ wet $\mathrm{SO}_{4}{ }^{2-} \mathrm{ha}^{-1} \mathrm{y}^{-1}$ target load $\left(=416 \mathrm{eq} \mathrm{ha}^{-1} \mathrm{y}^{-1}\right)$ first proposed in 1983 for moderately sensitive aquatic ecosystems in eastern Canada (see discussion in Jeffries et al. 2003). The mean CL (176 to $400 \mathrm{eq} \mathrm{ha}^{-1} \mathrm{y}^{-1}$ ) are similar to the Ontario and Quebec provincial CL determined by Jeffries \& Ouimet (2005).

In Canada it has been customary to adopt the $5^{\text {th }}$ percentile CL value from a regional dataset in order to provide protection for $95 \%$ of the threatened ecosystems. Table 4 includes the $5^{\text {th }}$ percentile value for each of our sampling blocks. The sensitive (low $\mathrm{Cb}$ ) component of our survey lakes results in very low $5^{\text {th }}$ percentile CL values for all of our sampling blocks (range 1.9 to 52.7 eq $\left.h^{-1} y^{-1}\right)$, particularly the most northerly Blocks C through $\mathrm{H}$ and Block $\mathrm{J}$ (range 1.9 to $8.5 \mathrm{eq} \mathrm{ha}^{-1} \mathrm{y}^{-1}$ ). Blocks I and $\mathrm{K}$ near the Shield margin in SK had the highest CL among the 10 Blocks. The CL value for the SK ENV survey (Tab. 4) falls within the range of values for Blocks G, H and I where the surveys overlapped. The much higher CL determined for the VI and HBMS surveys are due to the higher $\mathrm{Cb}$ levels in their sample lakes.

The AURAMS model estimates wet and dry deposition on a $42 \mathrm{~km}$ grid for a number of atmospheric $\mathrm{S}$ and $\mathrm{N}$ species. For our survey lakes, AURAMS estimates of total S deposition varied from 67 to $1320 \mathrm{eq} \mathrm{ha}^{-1} \mathrm{y}^{-1}$ and total $\mathrm{N}$ deposition varied from 40 to $140 \mathrm{eq} \mathrm{ha} \mathrm{h}^{-1}$. Minimum estimated deposition (both species) occurred for lakes in Blocks C and D in MB blocks while maximum estimated $\mathrm{S}$ deposition occurred in Block $\mathrm{A}$ that is nearest the smelter $\mathrm{SO}_{2}$ source at Flin Flon (Fig. 1). Maximum $\mathrm{N}$ deposition was estimated for a lake in Block $\mathrm{H}$, the block closest to the large $\mathrm{NO}_{\mathrm{x}}$ emissions associated with oil sand processing near Fort McMurray, AB. AURAMS estimated even greater deposition for some of the lakes in the other surveys, i.e., total $\mathrm{S}$ estimated for a lake near Thompson, MB from the VI survey was $3300 \mathrm{eq} \mathrm{ha}^{-1} \mathrm{y}^{-1}$ and total $\mathrm{N}$ deposition for a lake near the AB border in the SK ENV survey was $230 \mathrm{eq} \mathrm{ha}^{-1} \mathrm{y}^{-1}$.

Using the same protection rationale that defined regional CL values, $95^{\text {th }}$ percentile exceedances for our survey blocks and the three other surveys are shown in table 4. All of our sampling blocks and the SK ENV survey have positive exceedances, both in the current situation (the $\mathrm{N}$-leaching exceedance) and in the case where the lakes ecosystems become $\mathrm{N}$ saturated (the Steady-state exceedance). Since $\mathrm{NO}_{3}^{-}$concentrations in our survey lakes are almost always below the analytical 
limit of detection (i.e., $<2.9 \mu$ eq $\mathrm{L}^{-1}$ ), the N-based component of the N-leaching exceedance is very small. Hence, for these MB and SK lakes, the N-leaching exceedance is almost completely a S-based value, and the difference between the N-leaching and Steady-state values reflects a possible future contribution to the exceedance by the current level of $\mathrm{N}$ deposition should it continue until an ecosystem steady-state is obtained.

Since exceedance is the difference between acidifying deposition and the $\mathrm{CL}$, positive values can occur either because the deposition is high or the CL is low. Here the positive exceedances are primarily due to the latter. For higher CL (as was the case for the VI and HBMS data sets), the current exceedance is negative.

\section{DISCUSSION}

Prior to the surveys reported here, most chemical data available for assessing lake sensitivity and acidification status in northern and central MB and SK were very old (often collected in the 1980s or earlier), limited in number and geographical coverage, focused on large lakes, or collected for other reasons, e.g., evaluating the quality of drinking water supplies. Therefore, they were unrepresentative of the lake populations in western Canada that are likely to be affected by acidifying emissions. Our surveys, conducted using stratified-random sampling designs, now provide chemical data representative of 81,494 lakes located within the survey domain. Note however, that for logistical reasons we did not include in our target population the approximately equal number of lakes $<1$ ha in area. The acidification sensitivity and status of these extremely small lakes has not been assessed.

An inventory of lakes $\geq 1$ ha for our survey domain has not existed in a quantitative, digital form until now. This lack of fundamental water resource information has a historical parallel. At the beginning of the acid rain research and monitoring program in eastern Canada in the 1970s, there was also no digital lake inventory until one was developed by Hélie et al. (1993). Lakes in a broad range of sizes and regional densities are an important landscape feature in central and northern MB and SK. On average, the lakes are not very deep which presumably reflects the rather low relief of this part of Canada. Like other locations on the Canadian Shield in eastern Canada, small lakes are a particularly important component of the inventory in terms of numbers; $19 \%$ of the lakes in our survey domain are 1 to 2 ha in area. Although not a significant proportion of the lake resource by area, such small water bodies are important habitat for migratory waterfowl. Conversely, the large lakes ( $>500 \mathrm{ha})$ in the survey domain are renowned for recreational angling.

All the indicators of acid sensitivity (Specific Conductance, $\mathrm{Cb}$ and Gran Alkalinity) showed a wide range with distinct regional patterns that are related both to the type of silicate bedrock and the quantity and nature of the glacial overburden [cf. the criteria used to develop the terrain sensitivity map in Environment Canada (1988)]. With the exception of Block K, every one of our sampling blocks contained some lakes with $\mathrm{pH}<6$, the generally accepted $\mathrm{pH}$ threshold that defines the onset of biological damage (Baker et al. 1990), and little capacity to neutralize additional acid inputs; hence, the very low regional $\left(5^{\text {th }}\right.$ percentile) $\mathrm{CL}$ determined by the SSWC.

Dissolved organic carbon is a very important constituent in many of the lakes. Leaching of humic and fulvic acids as water moves through organic soils yields the brown coloration and very shallow Secchi depths observed in many lakes. Drainage from the low relief, sometimes swampy terrain surrounding many of our sample lakes, yielded many highly coloured, high DOC samples (Tab. 3). DOC tended to be higher in small lakes, but there were cases of high DOC in all size classes. The combination of high DOC and high $\mathrm{Cb}$ and Alk is unusual in eastern Canada, but it is common in our surveys here and also in $\mathrm{AB}$ lakes to the west (WRS 2004). Natural organic compounds are generally amphoteric, that is, they can act as either acids (proton donors) at higher $\mathrm{pH}$ or bases (proton acceptors) at lower $\mathrm{pH}$. In high DOC waters, this amphoteric behaviour contributes both to a lower $\mathrm{pH}$ than would otherwise be the case (if DOC was absent), and to greater buffering against strong acid inputs. Use of the Lydersen et al. (2004) equation for $\mathrm{ANC}_{\text {limit }}$ is the way the SSWC compensates for this behaviour when calculating CL. If and how the high DOC lakes acidify will depend on the DOC-acidity interaction.

Lake surveys with statistically-based sampling designs have been conducted for the purpose of acidification assessment in northeastern and upper Midwest regions of the USA (Brakke et al. 1988; Eilers et al. 1988), in various countries and regions of northern Europe (Henriksen et al. 1998) and regions of southwestern Quebec (Dupont 1992). It is instructive to compare results from these surveys with ours. Average regional chemistry was reported as medians in the US and Europe and as means in Quebec. Denmark was one of the countries included in the northern Europe survey, and because its lakes are largely situated in calcareous terrain, the Danish data will be excluded from the comparisons that follow. The range in average block $\mathrm{Cb}$ concentrations for our survey $\left(189-681 \mu \mathrm{eq} \mathrm{L} \mathrm{L}^{-1}\right)$ was similar to the range in regional averages reported for the northeastern US (246-671 $\mu \mathrm{eq} \mathrm{L} \mathrm{L}^{-1}$ ), lower than that observed in the upper Midwest US (205-949 $\mu \mathrm{eq} \mathrm{L}^{-1}$ ), and greater than that in Europe $\left(79-240 \mu \mathrm{eq} \mathrm{L} \mathrm{L}^{-1}\right)$ and Quebec $\left(98-340 \mu \mathrm{eq} \mathrm{L}{ }^{-1} ; \mathrm{Ca}^{2+}+\mathrm{Mg}^{2+}\right.$ only). The ranges of our block average Alk and ANC concentrations (126-467 and 163-608 $\mu$ eq $\mathrm{L}^{-1}$ respectively) were higher than the range of regional averages for all the other surveys except those reported for the upper Midwest US. The high end of the range for the upper Mid- 
west $\left(802 \mu\right.$ eq $\left.\mathrm{L}^{-1}\right)$ was attributed to ANC concentrations in the Upper Great Lakes area - a region known to contain some calcareous bedrock and glacial tills. The range in our block average $\mathrm{SO}_{4}{ }^{2-}$ concentrations (14-60 $\mu$ eq $\mathrm{L}^{-1}$ ) was lower than those reported for all the other surveys (northeastern US, 75-159 $\mu \mathrm{eq} \mathrm{L}^{-1}$; upper Midwest US, 50-78 $\mu$ eq L L ${ }^{-1}$ Europe, $26-82 \mu$ eq L ${ }^{-1}$; and Quebec, $40-117 \mu$ eq $\mathrm{L}^{-1}$ ). The range in block average DOC concentrations $\left(6.8-20.6 \mathrm{mg} \mathrm{L}^{-1}\right)$ in MB and SK was much higher than those reported in all the other surveys (northeastern US, 3.8-5.2 $\mathrm{mg} \mathrm{L}^{-1}$; upper Midwest US, 4.6-9.2 $\mathrm{mg} \mathrm{L}^{-1}$; Europe, 1.9-8.6 $\mathrm{mg} \mathrm{L}^{-1}$; and Quebec, 5.3-8.0 $\mathrm{mg} \mathrm{L}^{-1}$ ). Note that the US and Quebec surveys occurred more than two decades ago, and the European survey more than one decade ago. Interpretation of the above comparisons must be tempered by the fact that lake chemistry in these regions has been changing as acidic deposition levels decline (Stoddard et al. 1999; Monteith et al. 2007).

The current level of S and $\mathrm{N}$ deposition in our survey domain is low relative to southeastern Canada except in the vicinity of the point sources at Thompson, Flin Flon and Fort McMurray. Sulphate concentrations in the lakes tend to reflect relative proximity to these sources. Nitrate levels are uniformly low (usually below analytical detection limits) suggesting that the boreal forest in their catchments is $\mathrm{N}$ limited. The low deposition levels and even lower $\mathrm{CL}$ values result in positive but generally small S-based exceedances for all of our sampling blocks (the Block A exceedance might be considered an exception). This new information for western Canada has only come to light because our survey design captured the sensitive component of the lake population, i.e., the lakes with low $\mathrm{Cb}$ that were absent from the assessment databases available to Jeffries et al. (2005). The recent VI and HBMS surveys contained few low $\mathrm{Cb}$ lakes as well, probably because their selection criteria had a minimum size restriction $(\sim 100 \mathrm{ha})$, and they sampled the less sensitive parts of MB and SK that surround the smelters. In any case, the positive exceedances signal a challenge to the current emission control strategy in Canada which is based on reducing deposition to CL levels.

HBMS has recently announced that it intends to cease smelting operations at Flin Flon in 2010. It remains to be seen whether or not this closure is permanent. The largest long-term acidification threat to the MB and particularly SK lakes is the expansion of oil sand processing in $\mathrm{AB}$. Not far downwind are some of Canada's most sensitive lakes. Lakes in SK north of our domain boundary $\left(58^{\circ} \mathrm{N}\right.$ latitude) may also be vulnerable to oil sands emissions, and a survey of this area is being conducted in 2009 .

\section{CONCLUSIONS}

Recent surveys of lakes designed to obtain a representative sample of the lake population in northwestern
MB and north-central SK have shown that a very sensitive component of the population is threatened by current levels of $\mathrm{S}$ and $\mathrm{N}$ deposition. However, at present there is only a small number of lakes with $\mathrm{pH}<6$. Aquatic effects may be alleviated to some degree by the announced closure of the smaller smelter source at Flin Flon, $\mathrm{MB}$, but additional acidifying emissions from the expansion of oil sand processing just west of SK (or even in SK) may increase the threat to a large population of very sensitive lakes in the west-central part of that province. Very high DOC levels in many lakes may yield acidification responses that differ from those observed in eastern Canada. A small subset of lakes should be selected for ongoing chemical and biological monitoring to quantify inter-annual variability and temporal trends.

\section{ACKNOWLEDGEMENTS}

Conducting surveys of the scale described here necessarily involves a large number of individuals. Susan Holland-Hibbert (Environment Canada, CIOB Applications - Toronto) was responsible for development of the digital lake inventories. Marion Seymour, Michael Burns, Andrew Gilchrist and Naomi Stewart were involved in field work preparation and post-survey data summarization. Earl Walker, Dan Walsh, David Gilroy, Roy Neureuther (all Environment Canada), Nicholas La Porte (MB Conservation) and Murray Hilderman (SK Environment) collected the lake samples. Chemical analyses were performed by Linda Irwin and her staff at the NRCan-GLFC laboratory. Fred Norouzian, Jill Franklyn and Paula Hunter (all Environment Canada) have been involved in the data processing required to produce this paper. Ken Scott (SK Environment) generously offered his SK ENV survey data for comparative purposes. Two anonymous reviewers offered many helpful suggestions that greatly improved the manuscript.

\section{REFERENCES}

Baker, J.P., D.P. Bernard, S.W. Christensen, M.J. Sale, J. Freda, K. Heltcher, D. Marmorek, L. Rowe, P. Scanlon, G. Suter, W. Warren-Hicks \& P. Welbourn. 1990. Biological effects of changes in surface water acid-base chemistry. NAPAP Rep. 13. In: P.M. Irving (Ed.), Acidic deposition: state of science and technology. Vol. II. Aquatic processes and effects. U.S. National Acid Precipitation Assessment Program, Washington, D.C.: 381 pp.

Brakke, D.F., A. Henriksen \& S.A. Norton. 1990. A variable $F$-factor to explain changes in base cation concentration as a function of strong acid deposition. Verh. int. Verein. Limnol., 24: 146-149.

Brakke, D.F., D.H. Landers \& J.M. Eilers. 1988. Chemical and physical characteristics of lakes in the northeastern United States. Environ. Sci. Technol., 22: 155-163.

Dupont, J. 1992. Québec lake survey: I. Statistical assessment of surface water quality. Water Air Soil Pollut., 61: 107124.

Dupont, J., T.A. Clair, C. Gagnon, D.S. Jeffries, J.S. Kahl, S.J. Nelson \& JM. Peckenham. 2005. Estimation of critical 
loads of acidity for lakes in northeastern United States and eastern Canada. Environ. Monit. Assess., 109: 275-291.

Eilers, J.M., D.F. Brakke \& D.H. Landers. 1988. Chemical and physical characteristics of lakes in the upper Midwest, United States. Environ. Sci. Technol., 22: 164-172.

Environment Canada. 1988. Acid Rain: a national sensitivity assessment. Inland Waters and Lands Directorate Environmental Fact Sheet 88-1, Ottawa, Ontario: 6 pp. (+ map, see also atlas.nrcan.gc.ca/site/english/maps/archives/ $5^{\text {th }}$ edition/environment/ecology/mcr4157).

Gibson, J.J., S.J. Birks, D.S. Jeffries, S. Kumar, K. Scott, J. Aherne \& D.P. Shaw. 2010. Site-specific estimates of water yield applied in regional acid sensitivity surveys across western Canada. J. Limnol., 69(Suppl. 1): 67-76. DOI: $10.3274 / J L 10-69-S 1-08$.

Hélie, R.G., G.M. Wickware \& M. Sioh. 1993. Quantitative assessment of surface water at risk due to acidification in eastern Canada. Environment Canada, Ottawa, Ontario: $95 \mathrm{pp}$.

Henriksen, A., P.J. Dillon \& J. Aherne. 2002. Critical loads of acidity for surface waters in south-central Ontario, Canada: regional application of the Steady-State Water Chemistry (SSWC) model. Can. J. Fish. Aquat. Sci., 59: 1287-1295.

Henriksen, A., B.L. Skjelvåle, J. Mannio, A. Wilander, R. Harriman, C. Curtis, J.P. Jensen, E. Fjeld \& T. Moiseenko. 1998. Northern European lake survey, 1995: Finland, Norway, Sweden, Denmark, Russian Kola, Russian Karelia, Scotland and Wales. Ambio, 27: 80-91.

Henriksen, A., B.L. Skelkvåle, L. Lien, T.S. Traaen, J. Mannio, M. Forsius, J. Kämäri, I. Mäkinen, T. Berntell, T. Wiederholm, A. Wilander, T. Moiseenko, P. Lozovik, N. Filatov, R. Niinioja, R. Harriman \& J.P. Jensen. 1996. Regional lake surveys in Finland, Norway, Sweden, northern Kola, Russian Karelia, Scotland, Wales 1995: coordination and design. Acid Rain Research Report 40/1996, Norwegian Institute for Water Research, Oslo, Norway: $30 \mathrm{pp}$.

Jeffries, D.S. \& R. Ouimet (Eds). 2005. Chapter 8: Critical Loads - Are they being exceeded? In: 2004 Canadian acid deposition science assessment. Environment Canada, Ottawa, Ontario: 341-368.

Jeffries, D.S., D.K. McNicol \& R.C. Weeber, R.C. (Eds). 2005. Chapter 6: Effects on Aquatic Chemistry and Biology. In: 2004 Canadian acid deposition science assessment. Environment Canada, Ottawa, Ontario: 203-278.

Jeffries, D.S., T.G. Brydges, P.J. Dillon \& W. Keller. 2003. Monitoring the results of Canada/U.S.A. acid rain control programs: some lake responses. Environ. Monit. Assess., 88: 3-19.

Lien, L., G.G. Raddum, A. Fjellheim \& A. Henriksen. 1996. A critical limit for acid neutralizing capacity in Norwegian surface waters, based on new analyses of fish and invertebrate responses. Sci. Tot. Environ., 177: 173-193.

Lydersen, E., T. Larssen \& E. Fjeld. 2004. The influence of total organic carbon (TOC) on the relationship between acid neutralizing capacity (ANC) and fish status in Norwegian lakes. Sci. Tot. Environ., 326: 63-69.

Monteith, D.T., J.L. Stoddard, C.D. Evans, H.A. de Wit, M. Forsius, T. Høgåsen, A. Wilander, B.L. Skjelkvåle, D.S. Jeffries, J. Vuorenmaa, W. Keller, J. Kopácek \& J. Vesely. 2007. Rising dissolved organic carbon in surface waters due to changes in atmospheric deposition chemistry. Nature, 450: 537-541.

Moran, M.D., Q. Zheng, R. Pavlovic, S. Cousineau, V.S. Bouchet, M. Sassi, P.A. Makar, W. Gong \& C. Stroud. 2008. Predicted acid deposition critical-load exceedances across Canada from a one-year simulation with a regional particulate-matter model. Proc. $15^{\text {th }}$ Joint AMS/A\&WMA Conference on Applications of Air Pollution Meteorology, Jan. 21-24, New Orleans, American Meteorological Society, Boston: $20 \mathrm{pp}$.

Poléo, A.B.S., K. Ostbye, S.A. Oxnevad, R.A. Anderson, E. Heibo \& L.A. Vollestad. 1997. Toxicity of acid aluminum-rich water to seven freshwater fish species: a comparative laboratory study. Environ. Pollut., 96: 129-139.

Scott, K.A., B.Wissel, J.J.Gibson \& S.J. Birks. 2010. Chemical characteristics and acid sensitivity of boreal headwater lakes in northwestern Saskatchewan. J. Limnol., 69(Suppl. 1): 33-44. DOI: 10.3274/JL10-69-S1-05.

Stoddard, J.L., D.S. Jeffries, A. Lükewille, T.A. Clair, P.J. Dillon, C.T. Driscoll, M. Forsius, M. Johannessen, J.S. Kahl, J.H. Kellogg, A. Kemp, J. Mannio, D. Monteith, P.S. Murdoch, S. Patrick, A. Rebsdorf, B.L. Skjelkvåle, M.P. Stainton, T. Traaen, H. van Dam, K.E. Webster, J. Wieting \& A. Wilander. 1999. Regional trends in aquatic recovery from acidification in North America and Europe. Nature, 401: 575-578.

UMA. 2007a. INCO Limited, environmental effects monitoring - sensitivity of Manitoba lakes to acidifying compounds, 2006 data report. UMA Engineering Ltd., Victoria, BC: 86 pp. (+ 3 appendices).

UMA. 2007b. Hudson Bay Mining and Smelting Co., Limited, natural lake chemistry and sensitivity to acidification: lakes within $400 \mathrm{~km}$ of Flin Flon, MB. UMA Engineering Ltd., Victoria, BC: 33 pp. (+ 3 appendices).

UMA. 2008. Vale INCO Limited and Manitoba Conservation, environmental effects monitoring - sensitivity of Manitoba lakes to acidifying compounds, 2007 data report. UMA Engineering Ltd., Winnipeg, MB: 40 pp. (+5 appendices).

UNECE. 2004. Section 5.4, Critical loads for aquatic ecosystems. In: Manual on methodologies and criteria for modeling and mapping critical loads and levels and air pollution effects, risks and trends. United Nations Economic Commission for Europe, Convention on Long-Range Transboundary Air Pollution, Geneva, Switzerland: V29V38. (see also http://icpmapping.org/cms/zeigeBereich/ 11/manual_english.html)

WRS. 2004. Calculation of critical loads of acidity to lakes in the Athabasca Oil Sands Region. Report to the $\mathrm{NO}_{\mathrm{x}}-\mathrm{SO}_{\mathrm{x}}$ Committee, Western Resource Solutions, Calgary, Alberta: 60 pp. (+ 9 appendices). 